
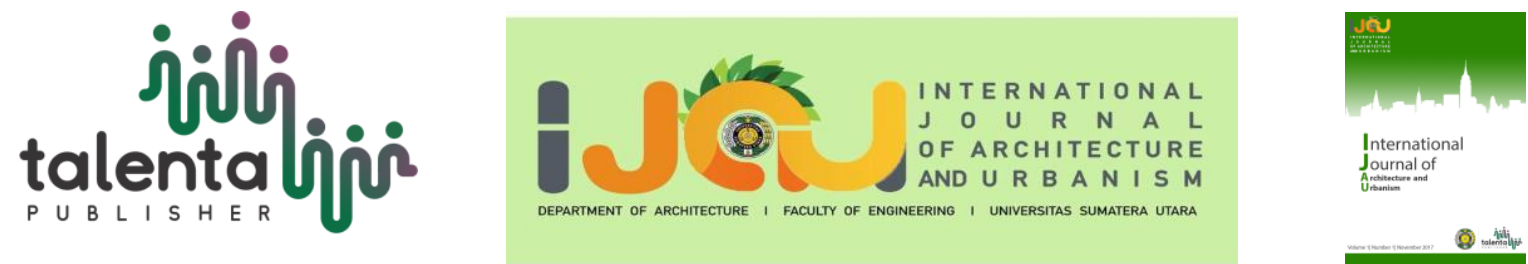

\title{
Islamic Center Design with Islamic Architecture Design Approach
}

\author{
Sri Gunana Sembiring ${ }^{1}$, Hastari Furqani ${ }^{1^{*}}$ \\ ${ }^{I}$ Department of Architecture, Faculty of Engineering, Universitas Sumatera Utara, Medan, Indonesia
}

\begin{abstract}
At the time of the Prophet, the mosque was a center for worship activities and economic activities, learning, socio-politics, etc. From this mosque environment, great figures in Islam were born who were not only strong in religion but also intellectually and mentally. However, the mosque has decreased in function now so that it is only a place of prayer. This phenomenon also occurs in the city of Medan, which is one of the largest cities in Indonesia, with the majority of the population being Muslim. Therefore, Medan often becomes the center of various activities, including Islamic religious activities in the area. Unfortunately, Medan does not yet have adequate facilities that can accommodate various Islamic religious activities, so it needs an activity center known as an Islamic center. The design of the Islamic center in the city of Medan solves design problems with an approach methodology ranging from literature studies, site surveys, and design concept analysis. This Islamic center applies a design concept by taking Islamic values that are not indifferent to the surrounding environment so that elements of the local culture are still considered. It is hoped that this Islamic center will not only be able to become a center of activity, especially Islamic religious activities in Medan, but also an area of learning about Islamic and local values in its design.
\end{abstract}

Keyword: Islamic architecture, Islamic center, Medan

Received 25 March 2021|Revised 27 July 2021 | Accepted 15 August 2021

\section{Introduction}

At the Prophet's time, the mosque had been designated as a center for the development of civilization in Islam. When the Prophet moved to Medina, he immediately built a small mosque in the Quba area. Arriving in Medina, he built the Prophet's mosque. An Islamic society developed based on monotheism from this mosque and created unity between the Muhajirin and the Ansar [1]. From here, too, formed the figures of Islamic leaders who were educated in the mosque area. They are not only taught about religion but also educated mentally and physically [2].

\footnotetext{
${ }^{*}$ Corresponding author at:Department of Architecture, Faculty of Engineering, Universitas Sumatera Utara, Perpustakaan st. Building J07, Medan, 20155, Indonesia

E-mail address: hastarfurqan@yahoo.co.id
}

Copyright $@ 2021$ Published by Talenta Publisher, 
The spread of Islam cannot be separated from the role of mosques as the center of the development of Islamic da'wah. However, recently, public awareness of the magnitude of the role of mosques has decreased; this is indicated by the number of mosques that are empty of activity. People today think that a mosque is just a place of worship, no longer the center of various activities as in the days of the Prophet [3]. History records that the mosque at the time of the Prophet Muhammad had multiple functions and its primary function as a center of worship. At that time, the mosque was used as a center of education, science, economic and social-political development [4].

To restore the function of the mosque as the mosque during the time of the Prophet and a period in which Islam experienced rapid progress, then began the idea that emerged among Indonesian Muslims to establish a forum in the form of an institution that was able to accommodate various activities of study, guidance, and development of religion and culture that are non-formal. This institution is in the form of an Islamic activity center or called the Islamic Center.

Medan City is one of the cities in Indonesia with a heterogeneous community with a majority Muslim population. Even today, Medan City, which is also the capital of North Sumatra province and one of the largest metropolitan cities in Indonesia, is still the center of Islamic religious activities in the region. Therefore, we need an Islamic Center that can accommodate these Islamic activities by considering environmental, social, and cultural aspects without abandoning Islamic principles.

\section{Literature Review}

The concept of Islamic architecture should have the nature of not damaging nature and following what is needed. Utaberta (2006) approached Islamic architecture by looking into the values that exist in Islam and then implementing it in building design. From this study, it was concluded that to understand and form the theoretical framework of Islamic architecture, an understanding of internal Islamic values is needed. He grouped the design principles into principles of remembrance of God, principles of remembrance of worship and struggle, principles of remembrance of life after death, principles of remembrance of humility, principles of remembrance of waqf and public welfare, principles of remembrance of cultural tolerance, principles of remembrance sustainable life and the principle of remembrance of openness, perhaps only a tiny part of the moral values that exist in Islam that allows this study to be developed more broadly and deeply in the future [5].

In the view of Islam, everything will be accounted for so that the use of fabricated things, irrational symbolization, and wasteful nature is prohibited. Not wasteful means are efficient to get optimal results. Included in the aesthetic element, it does not have to be luxurious and expensive, but it should also be functional [6]. Therefore, consideration of function was prioritized from the start. In this case, the Islamic Center building must be able to accommodate worship activities and other 
Islamic spiritual activities and supporting facilities such as trading activities, recreation, learning, etc. [7].

The application of these principles can be seen among others in Frank Lloyd Wright's design that blends with nature (Figure 1). The choice of building materials and ornamentation takes elements with characters that are following the surrounding natural conditions [8]. As a result, natural elements will dominate while buildings will look low and stand in harmony with their surroundings [9]. Although Frank Lloyd Wright is not a Muslim, his design methods and approaches seem more Islamic than many Muslim architects who prioritize Islamic symbols rather than the substance of his teachings. Besides the design and formation of the building period, natural elements such as sunlight, airflow, and the sound of water splashing need to be integrated into the building to create a harmonious relationship between humans and the natural surroundings as a means of forming a love for God [10].

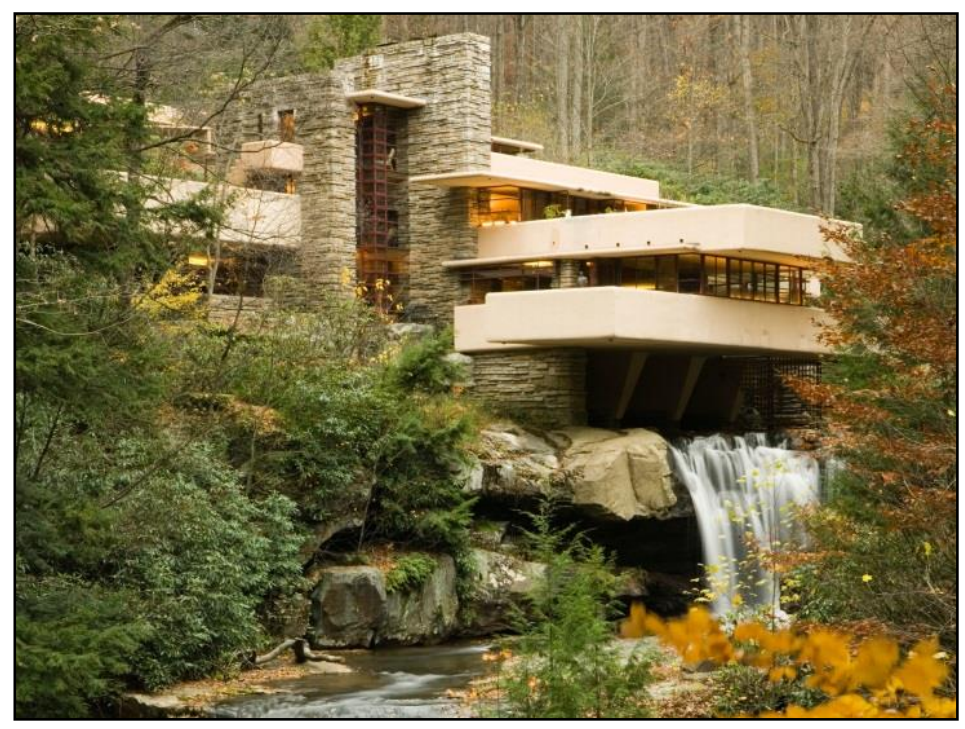

Figure 1 The Falling Water by Frank Loyd Wright

Another example of the application of Islamic architectural themes is the Salman ITB Mosque in Bandung. Salman Mosque ITB, Bandung is a crystallization of fragments of idealism and fundamental principles. This mosque does not take the character of a traditional mosque or mosque with a roofed dome that has been synonymous with Islam but refers to modern architectural concepts that are the trend at that time (Figure 2). The flat roof of the Salman mosque and the mihrab flanking walls use concrete material that is deliberately left without finishing, reminiscent of the brutalism of Le Corbusier in the 1960s. Functional aspects involved in the use of Kerawang, which act as aesthetic elements, also function as ventilation holes. The application of modern architectural ideology is revealed in the architectural form of Salman mosque, which is contemporary and offers architectural vocabulary that is unprecedented and considered unusual at the time. 


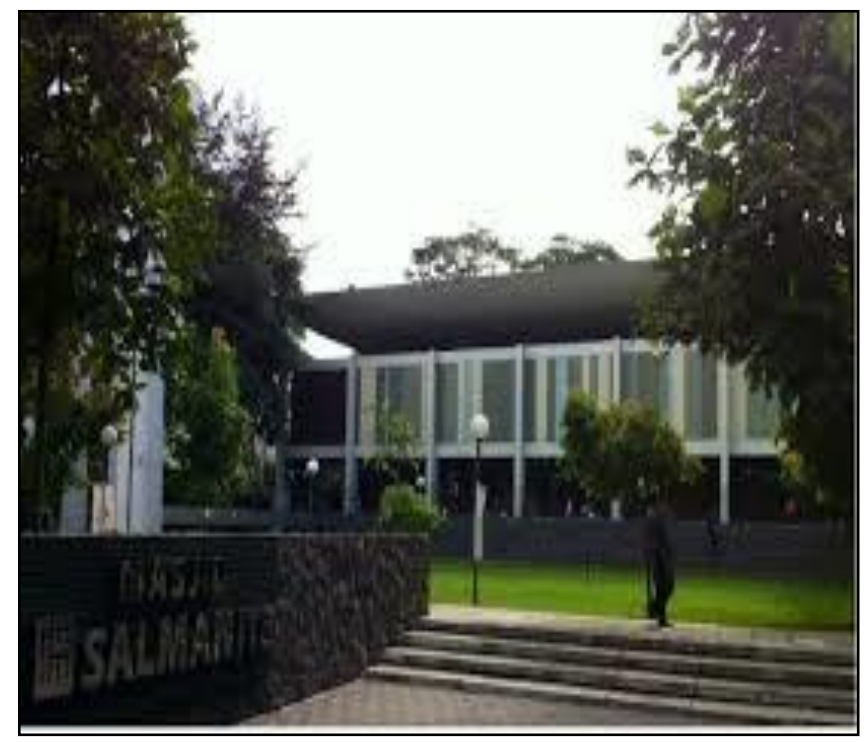

Figure 2 Salman Mosque

Salman Mosque ITB is a box-shaped base taken from geometric shapes. Modern architecture can be seen from the line and plane elements found in building facades. The building facade uses natural materials such as concrete Kerawang, the columns which are highlighted function as exterior elements in the building facade. The origin of the mosque roof form comes from the negative form of the ITB campus roof. The choice of shape like this comes from creating a widespread space underneath [11].

Salman Mosque ITB also applies the concept of green architecture in its design. Green building refers to structures and development processes that do not damage the environment and efficient use of resources ranging from materials, construction, design, building maintenance to economic and comfort [12]. The application of the green building concept in this mosque includes energy efficiency with lots of air and glass ventilation, water efficiency, environmental quality improvement because this building does not use AC (Air Conditioner), and optimization of building maintenance [13].

The tower is minimalist designed without simple ornaments and shapes. This tower serves to expand the reach of the call to prayer and regional landmarks and a feature that this is a mosque building.

Another example is the $\mathrm{Al}$ Osmani Mosque in Medan (Figure 3 ). Islamic architecture in the $\mathrm{Al}$ Osmani Mosque can be seen from its orientation towards the Kaaba, visible from the building's facade, leading to the qibla. There is a plain dome-shaped roof in the central part of the mosque. 


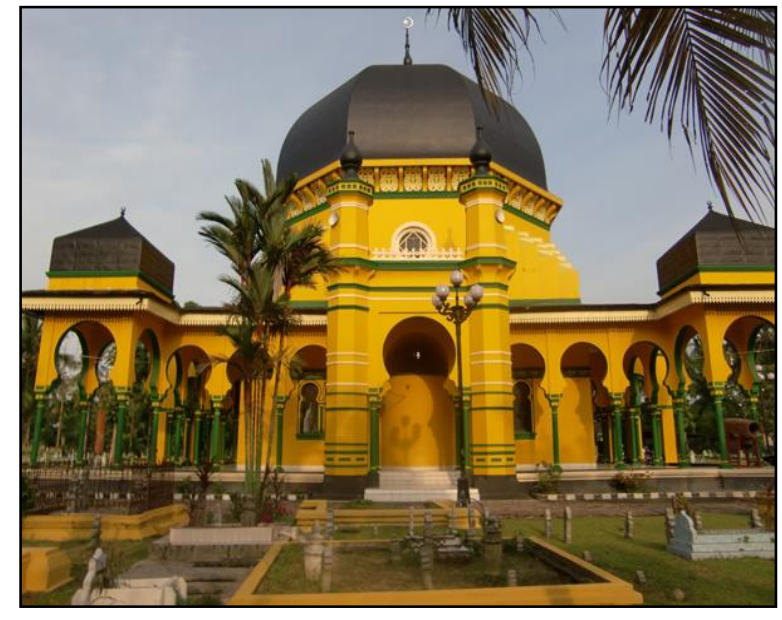

Figure 3 Al Osmani Mosque

The dome of the mosque uses the concept of Islamic theorist. It looks simple but still looks beautiful and not too flashy. Meanwhile, the porch is only a flat roof. It describes the simplicity of the mosque at the Prophet's time and reveals the simplicity of Muslims [14].

There is no minaret like the mosque in general in this mosque. There are only two large columns that look like the tower as a place for placing the loudspeakers. The absence of minarets, in no way, diminishes the beauty of the mosque. The Al Osmani Mosque looks beautiful and has a simple architectural design where simplicity is highly recommended, especially in mosque designs that use the Islamic Architecture concept.

The shape of the prayer room in the Al Osmani mosque is rectangular in which the sides are aligned with the qibla direction. The prayers at the mosque are designed column-free. There is not much ornamentation inside the room, and it looks simple with the same paint color as the exterior. The dominant paint on the walls is yellow and green, which are typical Malay colors. The yellow color means glory, and the green means a sign of Islam [15].

At Al Osmani Mosque, there are only spaces suitable for the mosque's needs in general, namely the prayer room, foyer, mihrab, and pulpit. Its simple and unobtrusive design and mosque orientation that leads to the qibla lays out the proper use of Islamic Architecture (Figure 4). 


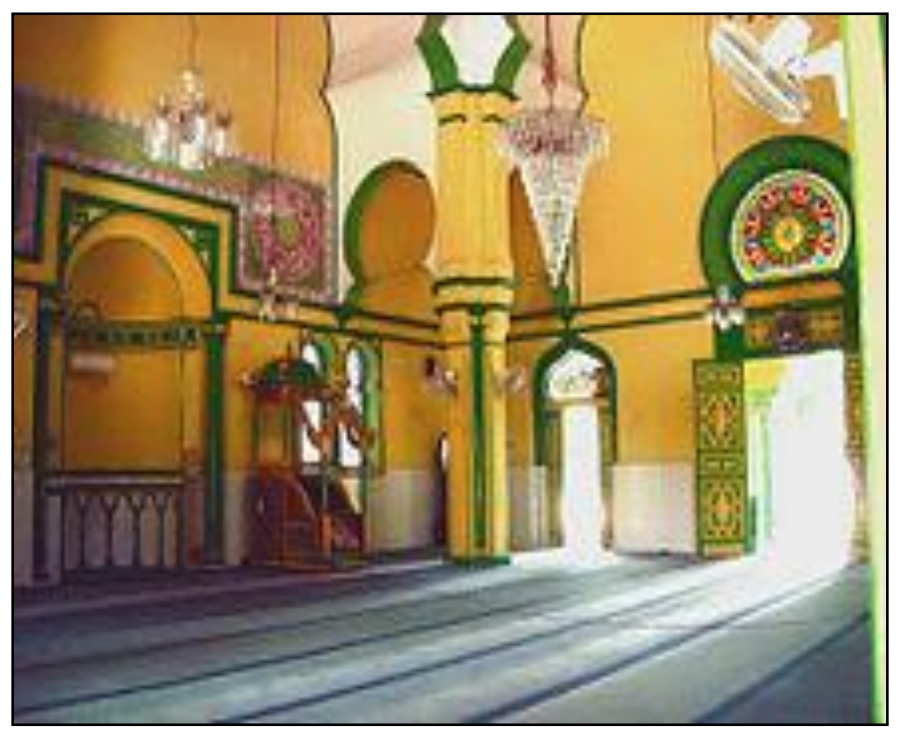

Figure 4 Interior of Al Osmani Mosque

\section{Methodology}

The design process of the Islamic Center started with a literature study, field survey on design location, user and action observation, and continued with site analysis and design concept appointment. There are also case studies to research similar project design cases. The approach of the design concept used is the thematic approach, where the design theme used is a theme of Islamic architecture.

A field survey was conducted on the location of the design, with the object of research is the site condition and the surrounding environment. The design process of the Islamic Center started with collecting data and processing data which was carried out by observing and documenting the situation around the site. Then proceed with literature studies and comparative studies on similar projects and projects with similar themes. After that, proceed with analyzing existing data such as the site, functions, user activity, circulation, space, and structure. From the analysis results, we will get an Islamic Center design concept with an approach to the predetermined concept.

\section{$4 \quad$ Result and Discussion}

The site's location is in Medan Tembung, precisely in the MMTC area with the main road nearby Jalan Willem Iskandar, which is a commercial area. In the area around the site, there are MMTC 
shopping complexes and high-density residential areas. Besides, there is MadrasahAliyah directly adjacent to the site (Figure 5).

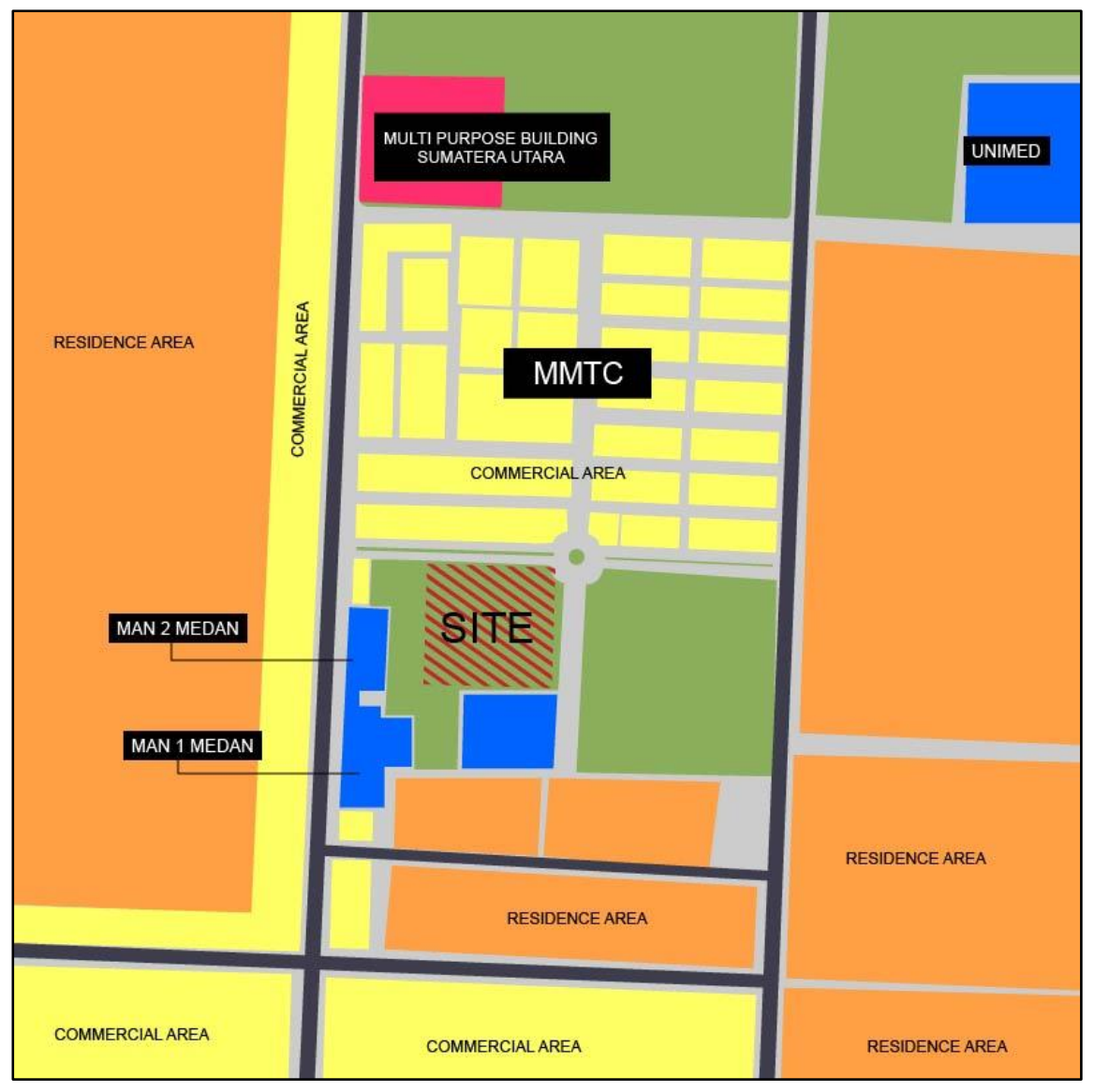

Figure 5 Public facilities around the site

The design of this Islamic Center emphasizes the concept of applying Islamic principles in a work of religious architecture that is not only used for worship but also with the addition of public facilities that are tailored to the needs of the community as a mosque in the time of the Prophet who has the same function large and many other than its main function as a place of worship. The various supporting functions in the design are expected to introduce to the broader community, both Muslim and non-Muslim, that Islam is very flexible and open to other activities besides worshiping in the mosque.

With various activities and functions on the site, it is necessary to have appropriate zoning, which is divided based on the type of activity and the characteristics of the activity. In general, the site is divided into three zones, namely the public zone, which is an area adjacent to the main entrance access, the semi-public zone located on the east side of the site, and the private zone located at the back to maintain the privacy of its users (Figure 6). 


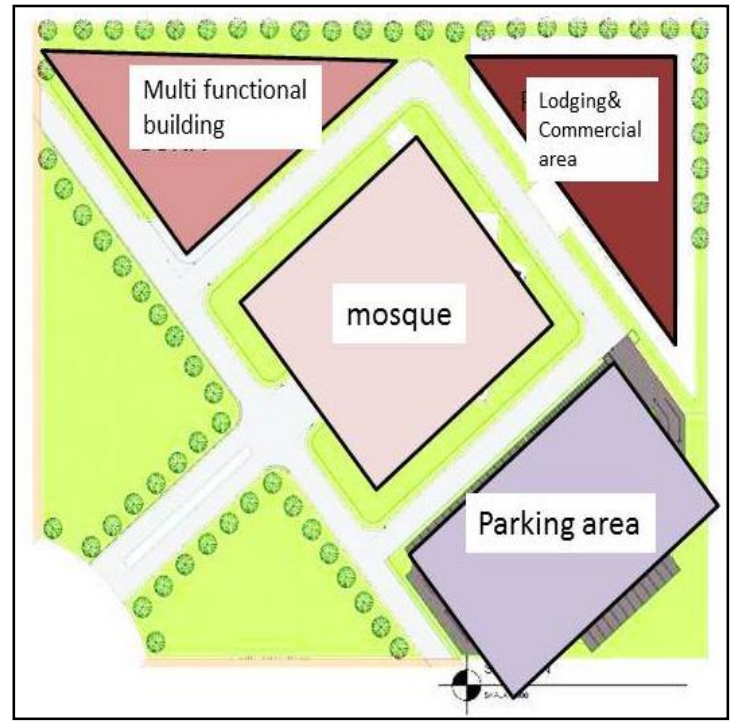

Figure 6 Zoning

In general, the site is oriented to one of the corners of the design site, which is a roundabout as a form of response to the environment. The mass orientation that needs to be considered is the mosque building that leads to the qibla. The orientation of the mass of the additional buildings follows the direction and site formation (Figure 7).

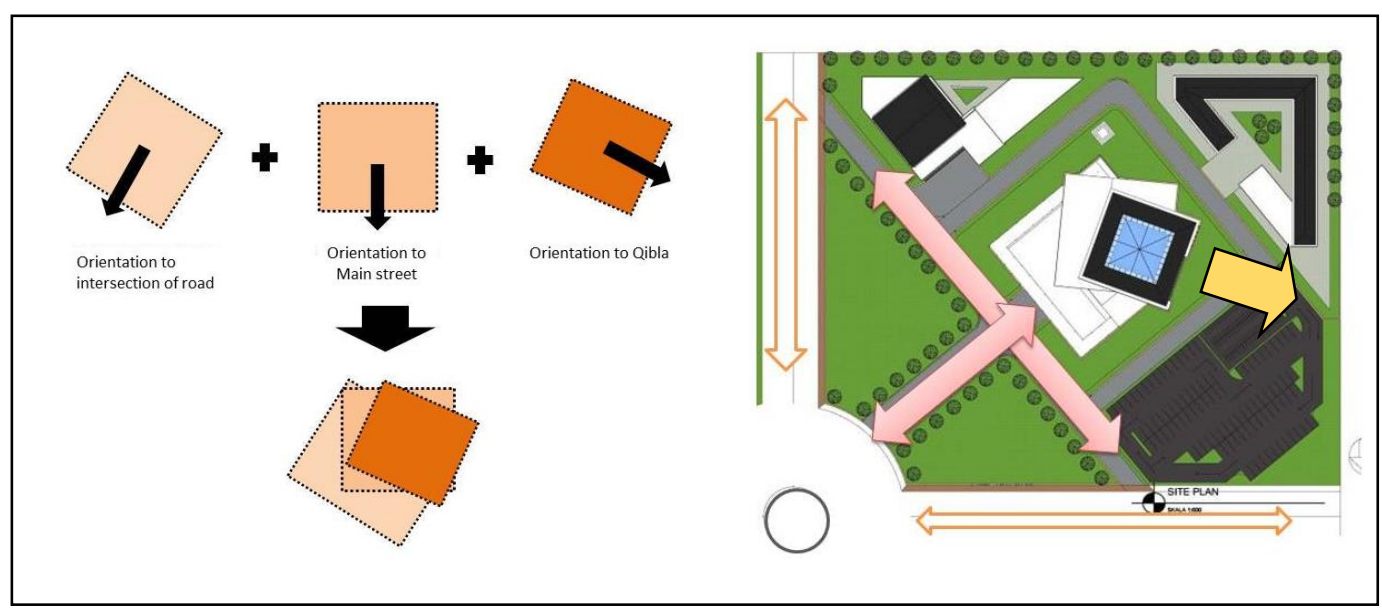

Figure 7 Buildings orientation

The consideration made in determining the mass formation is based on a study of Islamic architectural themes. It can be concluded that in Islam, it is demanded to use something as efficiently as possible and not wasteful. Referring form of design that comes from the most efficient basic formations. So, in general, the rectangular shape was chosen as the basic form of the main mass of the Islamic Center. At the same time, the supporting buildings follow the shape of the site remaining after the main mass is placed. The main facility at the Islamic Center is the mosque, which has always been the center of Islamic civilization in a region. Besides, other facilities support the activities in the mosque, such as a building, library, guest house, clinic, shopping area, and others, as well as supporting facilities such as parking and service areas. 
One concept that is of concern to the design of the Islamic Center is the concept of the building facade. The building facade is designed with a simple yet attractive nuance following the principle of simplicity in Islam. Excessive use of decoration on the facade is avoided. Facade design emphasizes the benefits to be gained from the design, not only as a decorative element (Figure 8).

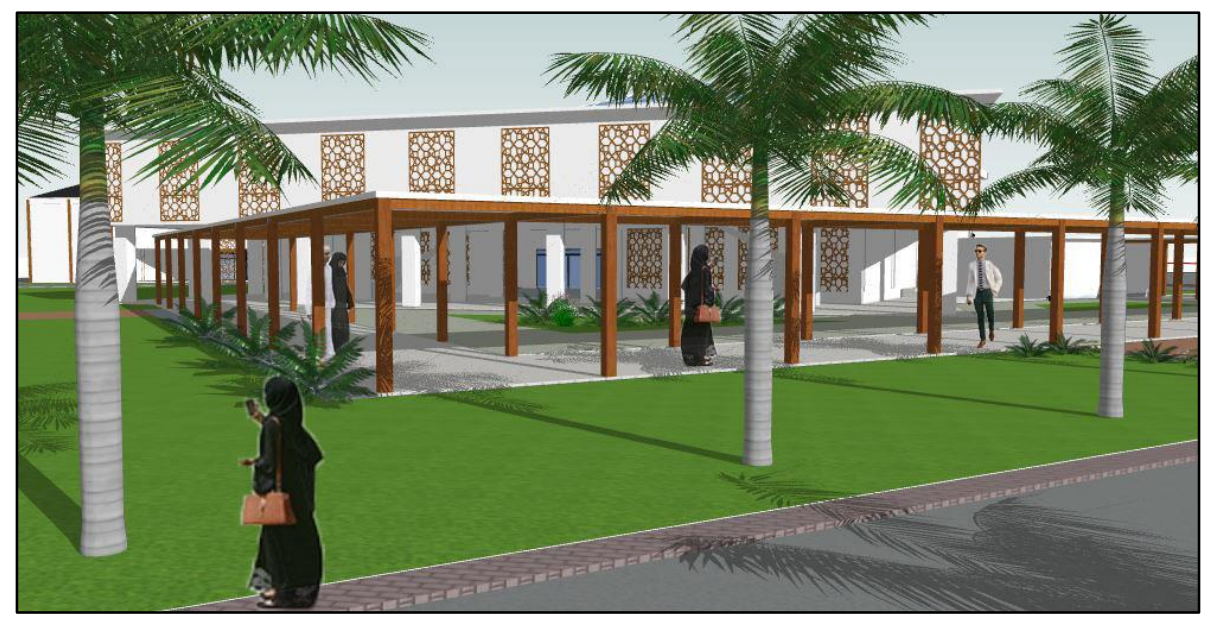

Figure 8 Simple design for the mosque

The concept of the facade of the building of the Islamic Center is based on architectural elements from the Islamic empire that developed in Medan, the Deli sultanate. The facade is inspired by the shape of the Malay house wall, which is vertically arranged boards called the Tindih Kasih arrangement (Figure 9).

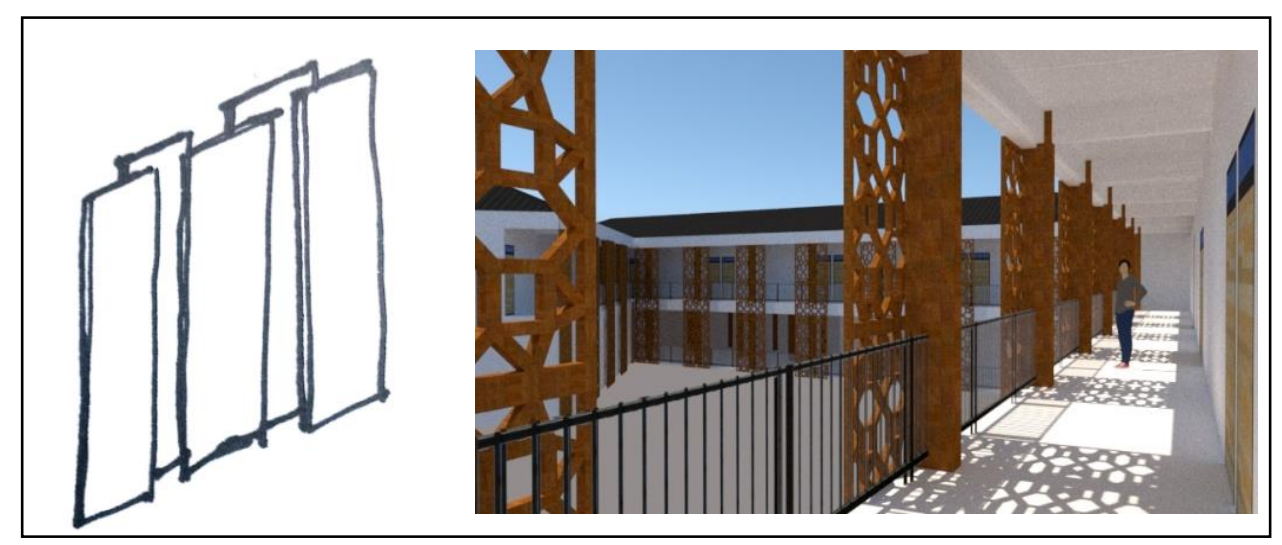

Figure 9 Secondary skin

\section{Conclusion}

Based on the background of the problem and the need for facilities for Islamic activities in Medan, it can be concluded that some solutions to the existing problems. The problem found is the lack of facilitation of Islamic religious activities in Medan. The Medan City government should provide such facilities in the form of an Islamic Center that can accommodate and accommodate these Islamic activities by considering environmental, social, and cultural aspects without leaving the principles. 
The activities accommodated in the Islamic Center are Muslim worship activities such as prayer, Quran recitation, and religious lectures; learning activities to add insight and knowledge; consultation and health clinics; and also complementary activities to support the Islamic Center's functions as trade and lodging.

It is hoped that with this Islamic Center, the activities of the people of Medan City and surrounding areas, especially those who are Muslim, can carry out various religious activities comfortably. It is also possible that this area can be visited by other people who are not Muslim to get to know Islam or stop by for a walk.

\section{Acknowledgment}

This research is a study on the design of the Islamic Center, which expect to be a recommendation for the city governments as a center of Islamic religious activities in Medan by applying the concept of Islamic Architecture.

\section{REFERENCES}

[1] Ramayulis, Sejarah Pendidikan Islam: Napaktilas Perubahan Konsep, Filsafat dan Metodologi Pendidikan Islam dari Era Nabi SAW sampai Ulama Nusantara, Jakarta: Kalam Mulia, 2012.

[2] M. Qomar, Menggagas Pendidikan Islam, Bandung: Remaja Rosdakarya, 2014.

[3] A. Saputra dan B. M. A. Kusuma, "Revitalisasi Masjid dalam Dialektika Pelayanan Umat dan Kawasan Perekonomian Rakyat," Al-Idarah: Jurnal Manajemen dan Administrasi Islam, 2017.

[4] U. K. N. Isnaini, B. R. Nyimasmukti, Y. Rahawarin dan Asrida, "Revitalizing the Mosques Function as a Means of Forming Muslim Scholars and Students in Indonesia," Khalifa: Journal of Islamic Education, vol. 3, no. 2, pp. 142-153, 2019.

[5] Sativa, "Arsitektur Islam Atau Arsitektur Islami?," NALARs, vol. 10, no. 1, pp. 29-38, 2011.

[6] Umar, "Integrasi Konsep Islami dan Konsep Arsitektur Modern pada Perancangan Arsitektur Masjid," Radial, vol. 2, no. 1, pp. 38-46, 2014.

[7] M. B. Edrees, "Konsep Arsitektur Islami Sebagai Solusi Dalam Perancangan Arsitektur," Journal of Islamic Architecture, vol. 1, no. 1, pp. 16-20, 2012.

[8] A. Tate, "Design with nature now," Landscape Journal, vol. 39, no. 1, pp. 87-89, 2021.

[9] T. Widati, "Pendekatan Kontekstual dalam Arsitektur Frank Lloyd Wright," Jurnal Perspektif Arsitektur, vol. 10, no. 1, pp. 38-44, 2015.

[10] U. Nangkula, "Rekonstruksi Pemikiran, Filosofi Dan Perancangan Arsitektur Islam Berbasiskan Al-Qur'an Dan Sunnah," Simposium Alam Bina Serantau Universiti Kebangsaan Malaysia, 2011. 
[11] I. Thonthowi, "Penerapan Konsep Islam Pada Perancangan Masjid Salman ITB Bandung (Application of Islamic Concepts in the Design of Salman Mosque ITB Bandung)," Jurnal Reka Karsa, vol. 01, no. 2, pp. 1-11, 2013.

[12] S. Shams dan M. M. Rahman, "Green Building," dalam Sustainable Utilization of Natural Resources, CRC Press, 2017.

[13] A. Sasmito dan N. Fariz, "Kajian Konsep Arsitektur dan Green Design pada Bangunan Masjid Salman ITB," Merdeka Indonesia Jurnal International, vol. 1, no. 1, pp. 1-10, 2021.

[14] Y. Syarah, "Penggunaan Konsep Arsitektur Islam Pada Bangunan Masjid Raya Lama AlOsmani Medan," Syajarah, 2018.

[15] R. Prayogi, "Analisis Ornamen pada Bangunan Masjid Al Osmani Medan," PROPORSI: Jurnal Desain, Multimedia dan Industri Kreatif, vol. 5, no. 2, pp. 217-226, 2021. 